\title{
Wrinkle lip pattern in smokers and non-smokers for identification in forensic dentistry
}

\author{
Teuku Muhammad Harqad*, Murnisari Dardjan *, Ine Suhartina \\ Hardjadinata* \\ *Department of Oral Biology, Faculty of Dentistry Universitas Padjadjaran
}

\begin{abstract}
Introduction: Lip prints can be used as one of support for identification Because it has a pattern or lip wrinkles that never the same (unique) in each individual. Smoking has become a common habit and widespread in the community. Prolonged heat stimuli from smoking can cause changes in the lip wrinkles. Methods: This descriptive study found the description of lip print patterns on smokers and non-smokers. Samples Obtained as many as 30 people chosen by Certain criteria. Direct observation was made through some white cardboard that had been printed of lip prints and divided into four quadrants. Each quadrant was observed with a magnifying glass and count the number of lip wrinkles. Results: The number of lip wrinkles on each quadrant and been jotted in a table. The result is varied in the number of lip wrinkles in each quadrant between the smokers and non-smokers. Conclusion: The lip prints pattern of smokers showed a result of 12 to 17 pieces of wrinkles, and the lip prints pattern of non-smokers have 8 to 12 lines of wrinkles.
\end{abstract}

Keywords: Lip Print, Smoking, Wrinkles

\section{INTRODUCTION}

Forensic Dentistry is a science and technology applied to dentistry in legal matters. This science is also called forensic odontology. Forensic odontology term comes from the Greek, odons is tooth and logos is knowledge, and the Roman, forensis or forum is the courts. Forensic odontology also can be interpreted as knowledge about the teeth for the court of law.

Forensic Dentistry previously incorporated in the Medical Forensic Science, but now become its separate science from Forensic Medicine. ${ }^{1}$ In many countries, Forensic Dentistry has received the most attention, but it has not happened in our country Indonesia. With the increasing number and types of criminality in Indonesia, Forensic Dentistry is needed in the process of identifying victims and perpetrators of crimes with conditions that are hard to recognize. Identification can be through the victim's organs that intact and recognizable. In Forensic Dentistry, identification can be made through the teeth and lip prints.

Cheiloglypia or lip prints are one of the support that can be used for identification because the lips pattern or groove were never the same (unique) in each individual. Besides, lip prints are fixed from birth, the same as the fingerprint. ${ }^{2}$ Lip prints can already be observed since four months old of the newborn. 
The smoking habit has become a very common and widespread in the community. In developed countries smoking has declined, whereas in developing countries is likely to increase. According to the study, the number of smokers in Indonesia is rising, especially among adolescents. ${ }^{3}$ Smoking motivation also has changed. It had only done at certain ceremonies but not for current, smoking is used to enhance the enjoyment of life and become a habit. ${ }^{4}$

World Health Organisation (WHO) has defined the current smokers as those who smoke every day for at least six months during his life. ${ }^{5} \mathrm{~A}$ smoker usually having difficulty to stop the habit because cigarettes contain nicotine that effects pharmacologically, encouraging habituation factors or psychological dependence. ${ }^{6}$ Smoking is associated with many chronic diseases, such as pulmonary and cardiovascular disease that have systemic effects and manifest in the oral cavity. ${ }^{7}$ Smokers often have wrinkles laterally at the top and bottom of lips because of the movement of the lips when inhaling and exhaling cigarette smoke. Smokers tend to smoke a few hours every day for years so that wrinkles become more severe. ${ }^{8}$

This research is about the description of the lip print pattern in smokers and nonsmokers by observing the number of wrinkles. The characteristic of smoker's lips print may be different due to keratinization and decreased elasticity. The purpose of this study is to know Wrinkle pattern of lip prints smokers and nonsmokers, for the identification process in the field of Forensic Dentistry.

\section{METHODS}

The type of research used is quantitative, and the writing used is a simple description writing, contains a true and accurate picture of the results of the inspection data collection and retrieval seal lip prints. The study population was 30 residents of Bandung. Samples are selected according to predetermined criteria (purposive sampling) such as do not have abnormalities in the mouth, old and young adults, whose are willing to be the subject of research (informed consent) and had smoked for more than one year. The materials used in this research are including lipstick for colouring the lips, white cardboard for placing lip prints, plywood $3 \times 6 \mathrm{~cm}$ for flattening the pressure when doing to take lips impression, cotton buds to apply lipstick, magnifying glass to observe the lips print pattern, informed consent as proof of respondent's consent, stationaries for filling the informed consent and record the results.

\section{RESULTS}

The research was conducted on 30 respondents, consisting of 15 smokers and 15 non-smokers. The location is in the area of West Java city of Bandung for two weeks in the third and fourth week of December.

Based on the results, there are differences in lip prints patterns between smokers and nonsmokers. This difference is seen in the results in the form of lip impressions of frown lines that tend to be more numerous in the smoker's lips.

There are 15 respondents chosen by the researchers. Lip printout of respondents observed and recorded the number of wrinkles in each quadrant in the table.

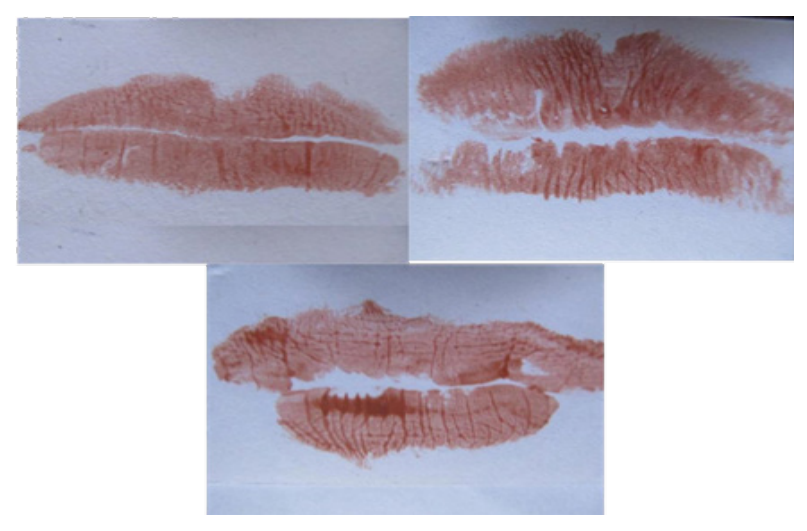

Image 1: The lips impression of the smokers

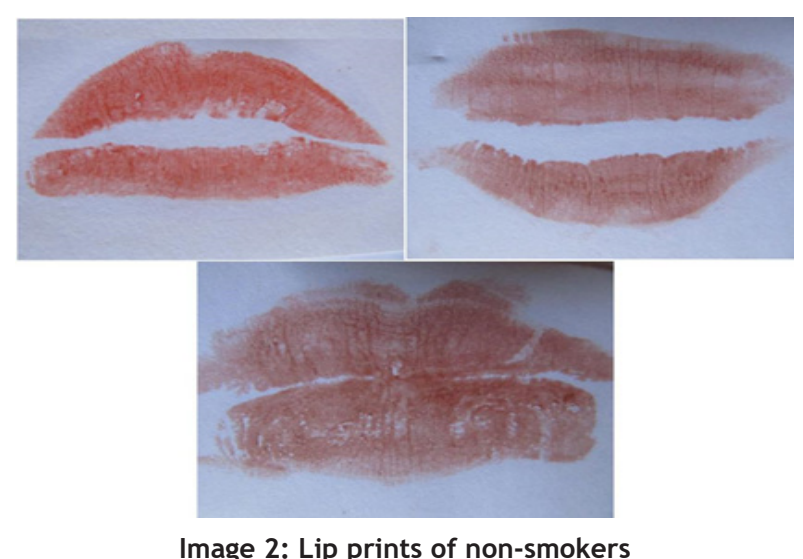


Table 1: Smokers' Data

In this research, 15 respondents do not smoke.
Results of research on the lip prints patterns of the non-smokers observed and recorded for each

quadrant in the table.

\begin{tabular}{ccccc}
\hline \multicolumn{5}{c}{ Number Wrinkles on Lips Print Patterns } \\
\hline Respondent & Quadrant 1 & Quadrant 2 & Quadrant 3 & Quadrant 4 \\
\hline 1 & 13 & 16 & 12 & 15 \\
2 & 13 & 12 & 15 & 16 \\
3 & 16 & 16 & 15 & 14 \\
4 & 13 & 14 & 16 & 12 \\
5 & 15 & 16 & 13 & 14 \\
6 & 16 & 14 & 16 & 16 \\
7 & 14 & 17 & 15 & 14 \\
8 & 17 & 13 & 16 & 14 \\
9 & 13 & 12 & 14 & 15 \\
10 & 15 & 15 & 16 & 15 \\
11 & 17 & 14 & 17 & 16 \\
12 & 15 & 15 & 16 & 13 \\
14 & 13 & 15 & 14 & 13 \\
\hline
\end{tabular}

Table 2: Non-smokers' data

From the table above, there are no differences in the number of wrinkles significantly. Each quadrant has far fewer number of wrinkles and

uneven than the number of wrinkles on the lips

\begin{tabular}{ccccc}
\hline \multicolumn{5}{c}{ Number of Wrinkles on Lips Print Pattern } \\
\hline Respondent & Quadrant 1 & Quadrant 2 & Quadrant 3 & Quadrant 4 \\
\hline 1 & 11 & 9 & 11 & 12 \\
2 & 10 & 11 & 8 & 8 \\
3 & 10 & 8 & 9 & 12 \\
4 & 11 & 10 & 12 & 11 \\
5 & 9 & 11 & 11 & 9 \\
6 & 9 & 10 & 11 & 9 \\
7 & 8 & 9 & 8 & 10 \\
8 & 10 & 9 & 11 & 9 \\
9 & 11 & 10 & 9 & 9 \\
10 & 9 & 8 & 12 & 12 \\
11 & 11 & 11 & 11 & 10 \\
12 & 10 & 9 & 10 & 11 \\
15 & 11 & 11 & 10 & 8 \\
\hline
\end{tabular}

of the smoker. For each respondent, the number of wrinkles in each quadrant is not a significant difference. Differences between the wrinkles in each quadrant only amounted to three only. The differences are likely due to environmental and lifestyle factors other than smoking.

\section{DISCUSSION}

Based on research data, 30 of the lip print pattern 
shows different results between the pattern of lip prints smokers and non-smokers. The effects of heat from smoking capable of changing network conditions lip mucosa becomes more coarse (more wrinkled). This happens because prolonged stimulation of heat from smoke, then there is the process of formation of keratin keratinization of the mucosa of the lips so that the network structure becomes rougher, and the reaction of self-defence against heat. ${ }^{4}$

The habit of a smoker, namely how he smokes can be seen from the research data. Some of the samples have a different number of wrinkles on the left side than on the right side of the lip or vice versa. It can be concluded that smokers have a smoking habit on one side of the lip. However, this habit should last long, because smokers need to smoke with this habit a few hours every day for years so that wrinkles become severe enough. ${ }^{8}$

In each quadrant calculated the average number of the wrinkles, lip print pattern data found smokers in quadrant one fruit 14.8, 14.3 quadrant two pieces, three 15 pieces quadrant, and quadrant four pieces 14.6. It can be concluded that from 15 smoker respondents, tend to smoke on the side of the left lip. The average number of li wrinkles patterns of nonsmoker's in quadrant one 9.9, quadrant two 9.6, quadrant three 10.2 and quadrant four is 9.8 units. Judging from the results of this study, it can prove that smokers using the muscles around the mouth, and this makes them more likely to have wrinkles around the lips than non-smokers. Smoking can reduce skin elasticity until the wrinkle lines of the smokers' lip print can be seen clearly. ${ }^{9}$

\begin{tabular}{cccc}
\hline 14.8 & 14.3 & 9.9 & 9.6 \\
\hline 15.0 & 14.6 & 10.2 & 9.8
\end{tabular}

Figure 3: Average number of wrinkles in Smokers and nonSmokers

\section{CONCLUSION}

the Wrinkle pattern of lip prints on a smoker has several wrinkles as much as 12 to 17 lines, and the pattern of lip prints non-smokers have several wrinkles as much as 8 to 12 lines.

\section{REFERENCES}

1. Knight B. Simpson's Forensic Medicine. Edward Arnold: London. 1993

2. Suzuki K, Tsucihihashi Y. New Attempt of Personal Identification by Means Lip Prints. Indian Dent. Association. 1970

3. Sirait AM, Pradono Y, Toruan IL. Perilaku Merokok di Indonesia. Bul. Penel. Kes. 2002;30 (3):139-152.

4. Ruslijanto H. Manifestasi Dalam Mulut yang Sering Dijumpai pada Perokok dan Peminum Serta Kemungkinan TImbulnya Keganasan. Skripsi M.I.K.G. FKG Usakti: Jakarta. 1999

5. Depkes. Departemen Kesehatan. 2004. The Framework Convention on Tobacco Control (FCTC). Diakses Online Pada www. litbang.depkes.go.id/tobaccofree/media/ TheTobaccoSourceBook/BukuTembakau / ch.10-march.ino_SB1.mar04.pdf (diakses 19 Juni 2011).

6. Ruslan G. Efek Merokok Terhadap Rongga Mulut. J. PDGI. 1993;42(2):22-26.

7. Sudhana W. Peranan Kebiasaan Merokok Terhadap Insidensi Karies.Skripsi FKG UI. 2001

8. Kurz A. How to Erase Lip Lines From Smoking. 2009. Diakses Online pada http://ehow. com/how_5691199_erase-lip-lines-smoking (diakses 12 Juni 2011).

9. Susanto H. Efek Merokok Terhadap Kecantikan. Diakses Online pada http://finroll.com/ baca / 2572/Efek-Merokok-TerhadapKecantikan (diakses 12 Juni 2011). 